\title{
The analysis and perspectives of studying basic and special types of self-determination according to A.L. Zhuravlev's and A.B. Kupreichenko's concept
}

\author{
Anastasia E. Vorobieva*, Anastasia A. Akbarova \\ Institute of Psychology of Russian Academy of Science, Moscow, Russia \\ *Corresponding author. E-mail: aevorobieva@ya.ru
}

An analysis of Russian and foreign ways of understanding the phenomenon of self-determination has been performed. It has been found that the concept of individual and group self-determination by A.L. Zhuravlev and A.B. Kupreichenko is the most developed in modern Russian psychological science. Using the concept as a basis, the conceptual schemes (made by A.E. Vorobieva and A.A. Akbarova) of studies of personal, moral, social and economic self-determination were considered as the examples of the basic and special types of self-determination. Moral self-determination was studied with questions about ideas of morality, moral strategies and personality orientation, attitude toward unethical phenomena, ability for self-regulation and emotional intellect. Social and economic self-determination were studied with questions that show one's social level, satisfaction with economic and social status and their dynamics, a valuation of favorable circumstances for an increase of status and economic activity. Value and anti-value, spheres and forms of showing of social and living personality's activity were also determined. Fundamental differences (variability, success criteria, implementation in behavior, a level of ability to control a process, the role of external factors) and similarities (successfulness, a formation level, a range, dynamics, conceptions, strategy, values, factors) between the components of the conceptual schemes of these types of selfdetermination were identified. The principles of studying (proportion of basic and specific types of self-determination, a display of resultative, procedural and formal-dynamic characteristics, consideration of factors of different levels) of basic and special types of self-determination were suggested.

Keywords: basic and special types of self-determination, social self-determination, economic self-determination, life self-determination, moral self-determination, structure and factors of self-determination 


\section{Introduction}

Social changes that began in Russia in the 1990s entailed changes in a value system, success criteria and social regulators that caused a high level of uncertainty and a constant need for self-determination for every member of Russian society. A development and a reconsideration of one's life path has become a priority under the new conditions. Social and economic instability in Russia remain present, compelling a subject to be ready to reconsider her strategies, values and place in the society; thus, the results of personal self-determination research are in demand, making the scientific problem of self-determination one of the most relevant.

A self-determination phenomenon is related to a category of complex psychological phenomena. The need for research on this type of phenomenon is conditioned by the fact, that close and particular psychological phenomena are researched and developed well enough, which is the second reason for high scientific interest in the problem of self-determination.

The definition of a self-determination phenomenon varies between Russian and foreign psychology.

In a foreign psychological school of thought, self-determination is understood as the intrinsic motivation of person's activity. In the R.M. Ryan and E.L. Deci (2000) conception, self-determination is described as an ability to choose and to have a choice. This definition allows taking into account both an inner individual choice and objectively existing limitations for a freedom of choice. Self-determination includes one's environment management or result-oriented actions, but may also include a refusal of control. E. Deci (1980) suggests that self-determination is not only an ability but also a basic human need. The selfdetermination definition is considered to be closely linked with a notion of personal freedom. G. Rychlak $(1979 ; 1981)$ sees the foundation of freedom in a subject's own ability to determine his or her own actions, to include his or her in a system of determination of his or her own activity and to restructure it, add goal determination to causal ones and proceed from his or her own wishes and goals based on them (Rychlak, 1984). R. Harré (1979; 1983), W. Tageson (1982) and J.A. Easterbrook (1978) are scientists who made a contribution to the development of this phenomenon. R. Harre posits the subjectivity and multilevel quality of human behavior regulation. W. Tageson understands psychological freedom as a self-determination force. He regards the self-reflection of determinants and activity restrictions as key components. G. Easterbrook has similar views, but he focuses his attention on the control over basic needs and the anxiety that arises from interaction with the outside world.

In our opinion, the Russian psychological school of thought regards self-determination in a wider sense, as a process of the long-lasting search for one's self, which may result not only in self-realization but also in a voluntary refusal of selfrealization for higher purposes, and it may also be a description of a group or a subject (A.N. Eremina, M.R. Ginzburg, A.L. Zhuravlev and A.B. Kupreichenko, N.S. Prjazhnikov, V.F. Safin). M.R. Ginzburg believes that personal self-determination does not stop in the teenage years. According to his studies, a personality comes to new self-determination through further development. V.F. Safin regards self-de- 
termination as a process of getting control over different life spheres, self-creation, self-affirmation. N.S. Prjazhnikov considers self-determination to be a constant search for "I-conception" and affirmation of it among other people. He regards selfdetermination as way beyond one's limitations. A.L. Zhuravlev and A.B. Kupreichenko draw attention to the fact that self-determination is life-long process and that it might coincide with self-realization, self-preservation and self-sacrifice at some life stages. The studies mostly touch upon personal self-determination. There are also a few groups of self-determination studies. For example, A.N. Eremina studies moral group self-determination with different levels of social-psychological maturity.

Another feature that sets the Russian approach apart is a differentiated study, subcategory distinction and correlation determination. In the foreign psychological school of thought self-determination has rather a universal nature.

Many Russian academics have dedicated their work to the topic of self-determination (K.A. Abul'hanova, I.I. Bashaeva, L.I. Bozhovich, A.V. Brushlinskij, T.M. Bujakas, M.R. Ginzburg, V.V. Guljakina, S.A. Ivanushkina, G.V. Ivanchenko, E.A. Klimov, L.A. Naumova, I.A. Oboturova, O.V. Ovchinnikova, A.K. Osnickij, A.V. Petrovskij and V.V. Shpalinskij, V.A. Petrovskij, G.S. Prygin and V.P. Farjutin, S.N. Prjazhnikov and E.Ju. Prjazhnikova, S.L. Rubinshtejn, V.F. Safin and G.P. Nikov, M.G. Ugarova, D.I. Fel'dshtejn, A.S. Chernyshev and others). Collectivistic, professional, personal and ethnic self-determination are the most researched topics. Moral, economic, social, religious, gender, life, spiritual, family and political self-determination are less researched. Different self-determination types have been researched mostly in relation to youth by I.I. Baskhajeva, L.I. Bozhovich, V.V. Guljakina, S.V. Dolmatova, N.I. Zajchenko, S.O. Zujeva, S.A. Ivanushkina, L.A. Naumova and N.S. Prjazhnikov. However, it has been suggested by reseachers such as N.N. Abramova, M.R. Ginzburg, A.L. Zhuravlev and A.B. Kupreichenko, S.A. Kalashnikova, O.V. Savvina and E.V. Kruglikova that self-determination as a life-long process. For this reason, the bounds of the research field have become broader.

According to S.L. Rubinshtejn's (1973) position, self-determination is a path of personality development. It is an inner determinant of behavior motives. $\mathrm{He}$ also drew attention to the fact that a process of life recomprehension occurs constantly and is characterized by striving for spiritual categories. In K.A. Abul'hanova-Slavskaja's (1991) opinion, self-determination is an awareness of a person's position that is formed inside the coordinates of the relationship system. Developing the ideas of S.L. Rubinshtejn, she marks important elements of self-determination, including one's determination, activity, conscious striving for determinate position (Abul'hanova-Slavskaja, 1973). In the works of L.I. Bozhovich (1968), the need for self-determination is regarded as the need for a certain personality system of meanings. According to V.F. Safin and G.P. Nikov (1984, p. 67), in a psychological sense, a self-determined personality belongs to a subject who has realized what he wishes (goals, life plans, ideals), what he is (his personality and physical characteristics), what he is able to do (his capabilities, predisposition, talents), and what a society expects of him; he is a subject who is ready to function in the system of social relationships. When they use the term 
self-determination, A.L. Zhuravlev and A.B. Kupreichenko (2007) mean a subject's search for his own way of life in the world, based on his perceived, accepted and formulated (created) basic relations to the world, humanity and himself with respect to time, as well as to his own system of life-meanings and principles, values and ideals, opportunities and expectations. In summary, all of the definitions given to this phenomenon denote its procedural nature, awareness and the subject's search for a place in life. The definition given by A.L. Zhuravlev and A.B. Kupreichenko shows the complete essence of the phenomenon, those inner factors that motivate a life-long pursuit.

There are several ways of understanding the self-determination phenomenon structure. The widespread model is based on the struture of the psychological relation. It includes cognitive, emotional and connotative components. The triangular structure can be supplemented with value, as well as motivational, communicational and other components (Bashaeva, 2005; Naumova, 2005; Padalko, 1998; Safin, Nikov, 1984; Ugarova, 2004). Some other authors base the structure of self-determination on motivation. (Borisova, 1995; Klimov, 1996; Safin, 1985; Safin, 1986). In the opinion of A.B. Kupreichenko, the most detailed structure and the most complete analysis of a self-determination content were presented by M.R. Ginzburg (1996). He highlights space-time and contextual-meaning elements of self-determination. His model includes the psychological present and psychological future. The psychological present consists of two elements: value and meaning core (which is a factor in self-learning) and self-realization. The elements of the psychological future are contextual future (which provides a contextual perspective) and temporal future (which provides a temporal perspective). However, A.B. Kupreichenko (2007) denotes some limitations of this model and other self-determination models. These limitations are: 1) the lack of a moral dimension; 2) the lack of analysis of a psychological past; 3) the lack of attention and description of formal-dynamic characteristics of self-determination; 4) the main elements of self-determination are not differentiated according to a significance level for a subject and temporal stability; and 5) the lack of links between the elements of self-determination. V.V. Guljakina (2000) outlines the lack of a general complete conception of the self-determination phenomenon in the scientific literature and the insufficient systematization of the existing information. M.G. Ugarova (2004) draws attention to a lack of a universal method in the determination of a professional self-determination structure. Based on the aforementioned unsolved problems around the self-determination phenomenon, A.L. Zhuravlev and A.B. Kupreichenko (2007) offer their own multilevel selfdetermination model for a group and personality, as well as principles of the study of the phenomenon. This concept advanced the scientific understanding of the phenomenon, and became the foundation for a number of studies that relied on its concepts.

\section{Methodology and research basis}

According to the conception of A.L. Zhuravlev and A.B. Kupreichenko (2007), there are two components in the structure of self-determination: a rigid core and a plastic shell. The core contains conceptions about the world and human society 
composition principles, the meaning of life, values and orientations, ideals and taboo, main life capabilities, principles and aspirations. The shell includes conceptions about the surrounding socio-psychological space: values, goals and motivations of different life stages; knowledge of a person's own capabilities and opportunities on each life stage; and a person's readiness for certain actions, connected to an attainment of a desired position in a social-relationships system during each life stage. A hypothesis about a more complex five level structure of self-determination was also suggested. It consists of the "axis" or life-guide (the most stable formation), a possible "transition zone" between the "core" and the "shell" and the "surface layer" of self-determination, which demonstrates a personality image and its atypical characteristics. However, in a number of studies performed by students and followers of A.B. Kupreichenko, a two-level self-determination model is used.

From the point of view of A.L. Zhuravlev and A.B. Kupreichenko (2007), this psychological phenomenon can be defined as a process, a property (characteristic of a personality or a group), or a subject's state ("cross-section" of the process on a certain development stage, its intermediate result). The authors define formaldynamic and contextual (procedural and effective) characteristics of self-determination. Formal-dynamic characteristics include a level of development, a range, a homogeneous/heterogeneous nature, proportionality and stability, situational stability/variability, universality/selectivity in different conditions, a process intensity, a dynamic nature and efficiency.

The term procedural characteristics includes life strategy, methods of achieving goals, ideas of necessary and permissible limits of activity levels, cycles and resource spending, guidance for information collection and analysis and rules of decision making.

The effective characteristics contain worldview and self-concept, values and ideas about their alteration, conceptions about world composition principles, basic attitude toward oneself and others, the entire world and expectations connected to it, attitude toward some elements of socio-psychological space, conceptions about one's own life perspective, evaluation of one's personal opportunities and abilities and goal-achieving criteria.

To continuing grouping the aspects of self-determination structure understanding suggested by A.L. Zhuravlev and A.B. Kupreichenko, we unite their model and M.R. Ginzburg's model into a structural-dynamic group.

After a critical evaluation of her predecessors' (A.K. Markova, N.S. Prjazhnikov and others) attempts to build the relative structure of self-determination types, A.B. Kupreichenko (2010) comes to the following conclusion. She regards spiritual and vital self-determination as basic. Spiritual self-determination includes gnostic (basic attitude toward world composition principles, society and human, expressed through "true - false" categories), moral and aesthetic self-determination. In the opinion of Kupreichenko, vital self-determination is both opposed to and supplemental to spiritual. It assumes a strategy identification for need satisfaction, physical survival and procreation. Personal and life self-determination are realized through these basic types. Social, economic, political and other types of self-determinations are based on these types and are considered to be special types. 
A.L. Zhuravlev and A.B. Kupreichenko (2008) formulated principles of empirical research organization of self-determination:

1) accounting for moral-value and life-meaning dimension;

2) temporal dimension analysis (through research on a subject's self-consciousness dynamics or through a subject's attitude toward to his or her past, present and future);

3) accounting for a stage nature of a subject's life and development;

4) accounting for a subjective properties of a human and a group;

5) emphasis on a transformative subject activity;

6) analysis and evaluation of content and formal-dynamic characteristics of self-determination;

7) analysis of content elements of self-determination based on how they differ in a significance level for a subject and temporal stability;

8) leaning on a necessary, bare minimum of self-determination components, which form hierarchically organized structure;

9) self-determination analysis from a subject's position.

The goal of this work is to extend one's knowledge and to apply a conception of self-determination of A.L. Zhuravlev and A.B. Kupreichenko to specific studies, making a comparative analysis of basic and special types of self-determination to extend the conception. We assume that basic self-determination research has both fundamental differences and some similarities with special self-determination studies. Accordingly, our main goal is to question the conceptual research schemes of moral and social and economic self-determination and to suggest our own perspectives for research on different self-determination types.

\section{Results}

Keeping in mind the task of researching one of the special types of self-determination, based on the aforementioned concept, it is necessary to create a conceptual model that takes into account the structure, characteristics and the relationship of the self-determination types suggested by A.L. Zhuravlev and A.B. Kupreichenko. For example, a conceptual scheme (Figure 1) was created in a complex study of social and economic self-determination made by A.A. Akbarova in a laboratory of social and economic psychology at the Institute of Psychology of the Russian Academy of Science. In connection with the fact that the core elements of any special type of self-determination are building blocks of the basic types (according to A.B. Kupreichenko), core elements of social and economic self-determination (self-concepts and conceptions about the world, values, life perspectives, possibilities, expectations, achievement criteria) are also the elements of basic, life selfdetermination. These elements can be classified as resultative characteristics of self-determination. Life self-determination is based on spirituality and vitality, so it immanently includes itself.

Elements of the shell (conceptions about the economic phenomenon, economic strategies, social activity) are at the same time the elements of social and economic self-determination and a fulfillment of a basic self-determination in spe- 


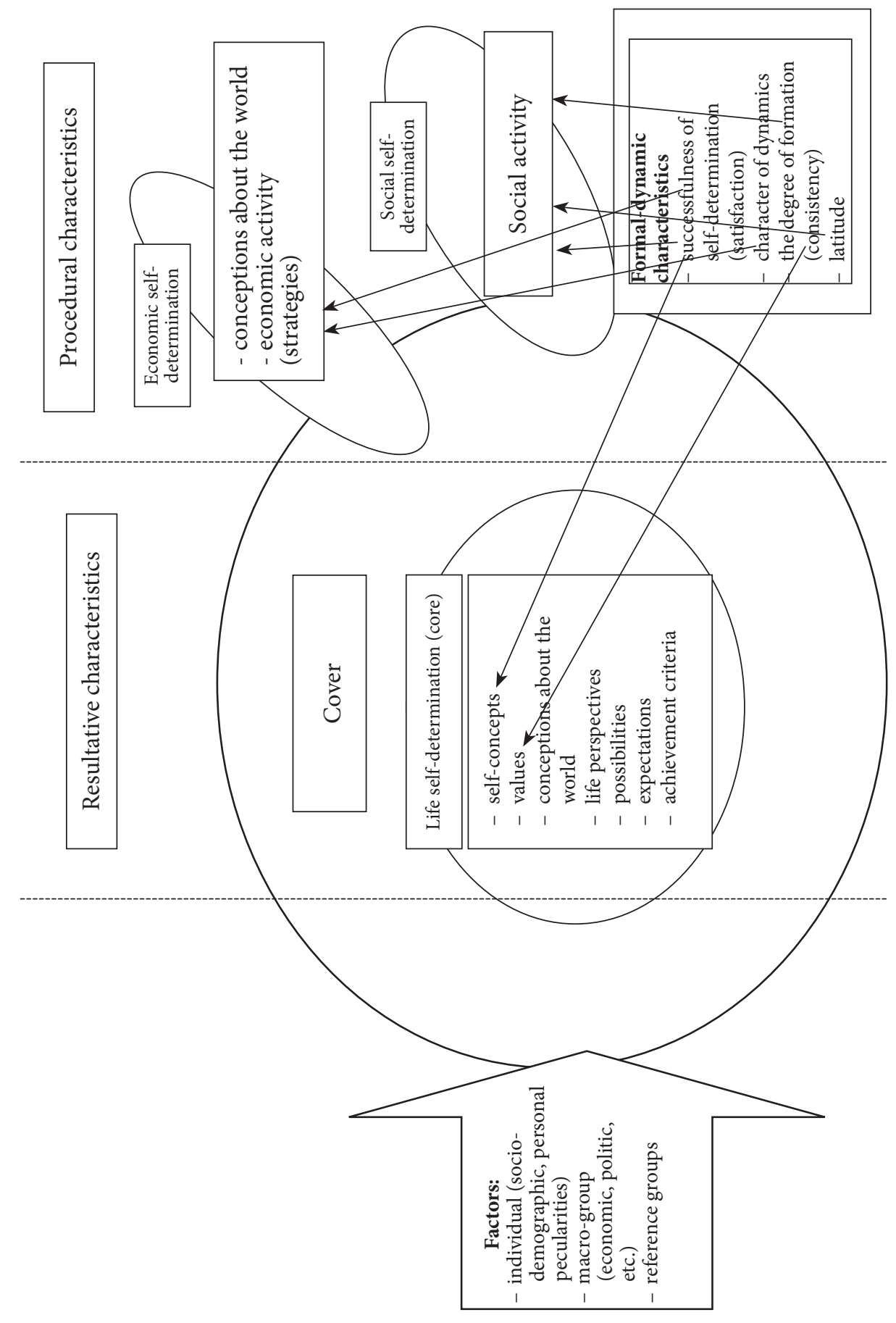

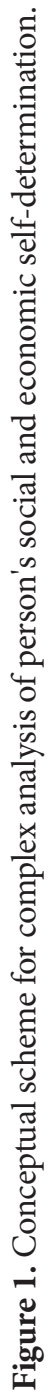


cific spheres of life. These elements can be assigned to procedural characteristics of self-determination. Moreover, formal-dynamic characteristics such as the successfulness of self-determination, dynamic nature and a level of formation can be researched through inconsistency/consistency of a personality's values, dynamic nature of life perspectives in social and economic spheres, satisfaction with one's own social and economic status and self-concepts, and the range of social activity. Factors influencing any of the self-determination types (individual factors (sociodemographical belonging, personal features), group factors (reference groups) and macrogroup factors (economic, political and other)) cannot be ruled out either.

The conceptual scheme was produced in a research program that contained the following content blocks:

1) questions of one's own social status and criteria of first definition; questions about satisfaction with personal social and economic status and the nature of their dynamism; questions to determine the favorability of the settings for an increase in status; questions about the economic activity (attitude toward money, income sources, satisfaction with one's own economic activity, readiness to take economic risks, concurrence);

2) values and "anti-values" defined by L.M. Smirnov, importance of which is rated in relation to oneself and a country (Smirnov, 2003),

3) spheres and forms of personality's life and social activity;

4) identification of socio-demographic characteristics.

As an example of basic personality self-determination type, a conceptual scheme of person's moral self-determination (Figure 2) (carried out by A.E. Vorobieva under A.B. Kupreichenko supervision (Kupreichenko, Vorobieva, 2013) can be studied. Moral self-determination is one of the most studied by A.B. Kupreichenko types of self-determination phenomenon. She suggested a four-segment structure:

- $\quad$ self-determination in relation to morality as a part of social consciousness and social institute;

- self-determination in relation to the surrounding world's objects and phenomena;

- self-determination in relation other people, groups and a entire society from a moral point of view;

- self-determination in relation to oneself as a subject of moral relations.

It is worth noting that ideals and guides, which serve as a starting point from which further elements of self-determination are chosen, are particularly important. That is why, in the conceptual research scheme of moral self-determination, the central spot is reserved for these specific elements.

According to the scheme, a notion of morality and moral compass are parts of the core elements. Moral strategies and attitude toward unethical phenomena are considered as the shell elements. The aforementioned elements also fit into the four-segment structure of moral self-determination. An influence of social-economic and group factors and life events was considered through the prism of individual and personal features. 


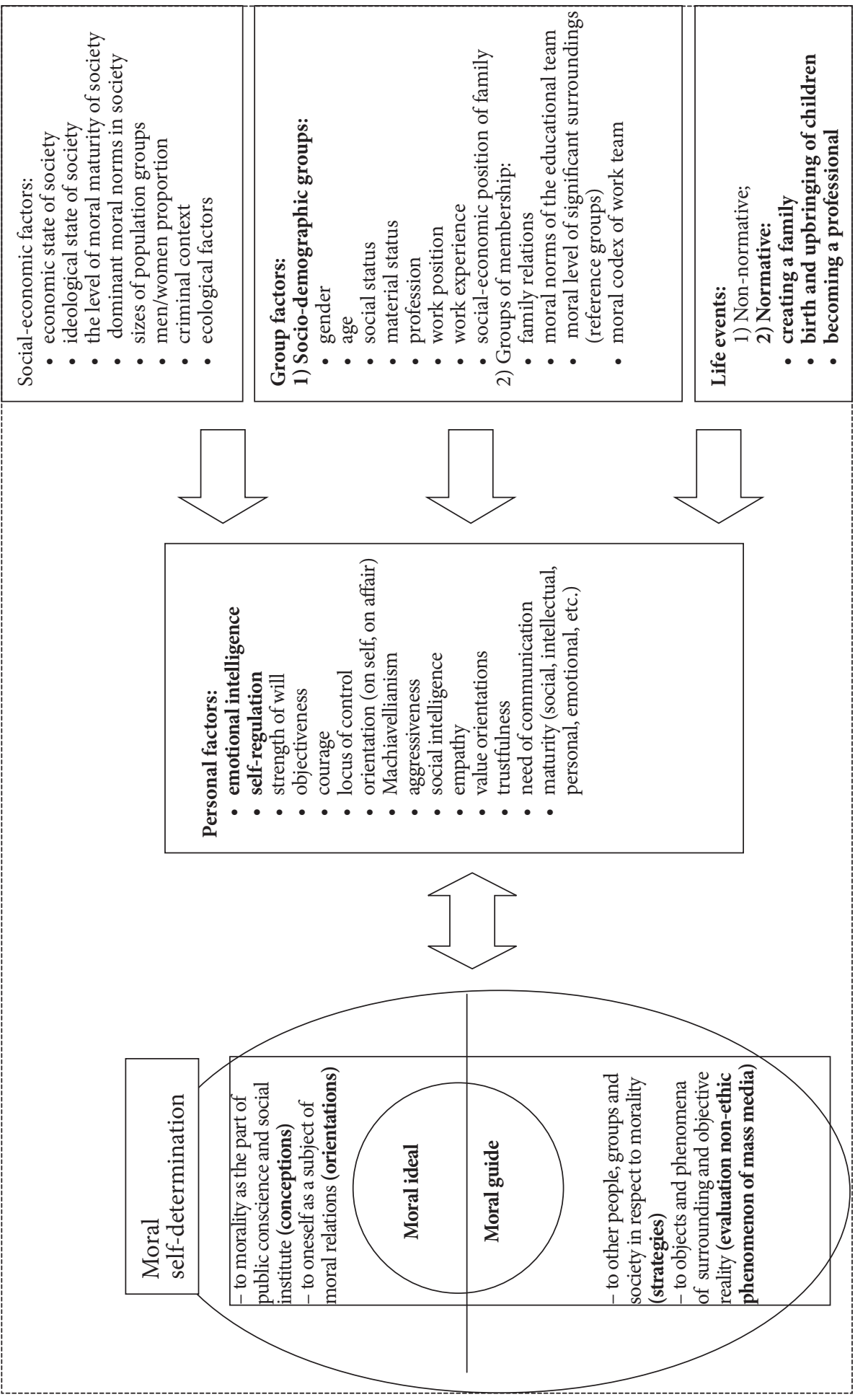

|0ं 
The conceptual scheme was produced in a research program, containing the following content blocks:

1) attitude toward unethical phenomena in mass media (TV advertisements and unethical words in newspapers headlines);

2) conceptions of morality and ethics (origins of morality as a phenomenon, significance of morality for the society, the absolute/relative nature of morality, a compensation for good and evil, personal morality (manifestation of one's strength or weakness, the nature of personal morality), moral strategies (a necessity of keeping the moral norms, activity or passivity of moral behavior, mutuality or non-mutuality of moral behavior), moral orientations (egocentric, group-centric, humanistic, world-creative);

3) An ability of self-regulation;

4) Emotional intelligence;

5) Identification of socio-demographic characteristics.

\section{Discussion}

The conceptual research schemes allow the definition of the following elements of moral (as an example of basic type), social, and economical (as an example of special type) self-determination:

1. Successfulness (index of successfulness/unsuccessfulness in moral self-determination is a classification of its result by total combination of positive or negative (thus, it has either a humanistic or antisocial nature); index of successfulness in context of social and economic self-determination is a level of satisfaction with one's own social and economic status);

2. Level of formation (the index of moral self-determination's formation is a coordination or lack of it between, on one hand, the ideas of morality, moral strategies and orientations and, on the other hand, attitude to unethical phenomena; in social and economic self-determination, level of formation is non-contradictoriness of values and "anti-values" because values are core elements of self-determination, according to A.L. Zhuravlev's and A.B. Kupreichenko's conception);

3. Range (a variety of application fields; there are potentially more fields for moral self-determination than there are for social and economic because moral self-determination, as well as the basic type, pierces all human activity spheres, but the number of them for a specific person may vary, depending on their moral orientation, cultural influence, etc.);

4. Dynamics (the index of it in moral self-determination are age cross-sections because of the moral changes in personality, which take place under the influence of new life experience, etc.; in context of social and economic self-determination, dynamics index is life perspective in a specific spheres, shown on subject's own expectations of graphics of changes in one's social and economic status);

5. Conceptions (in the context of moral self-determination, conceptions are ideas about the origins of morality as a phenomenon, compensation for good and evil, conceptions about morality as a manifestation of a personal strength or weakness, conceptions about the nature of personal morality; in a core of social and economic self-determination lay the conceptions of the world and self-concepts - see Figure 1); 
6. Strategies (strategies in moral self-determination are regarded as a strategy of necessity of keeping moral norms, a strategy of active or passive moral behavior, mutuality or non-mutuality of moral behavior; in context of social and economic self-determination, strategy means social and economic activity).

7. Values (in moral self-determination, values are conceptions about the significance of morality for society, conception about absolute or relative nature of morality; in context of social and economic self-determination, values and "antivalues" are discussed);

8. Factors (in programs of moral and social and economic studies personal, social-group and macro-social factors are taken into consideration - see Figure 1 and 2);

Based on the results of our own studies of moral and social and economic selfdetermination, we suggest some theoretical principles, which must be proven. We see some notable differences in particular elements and indexes of moral (as an example of basic type) and social and economical (as an example of private type) self-determination:

1. Moral self-determination is less variable and can be rigid and non-adaptive. Variability of moral self-determination may be regarded as negative (except for the cases of moral personality development), according to the conception of A.L. Zhuravlev and A.B. Kupreichenko (2007). This fact was also proven by a thesis by A.E. Vorobjeva (Vorobjeva, Kupreichenko, 2013).

2. Success criteria of moral self-determination are completely different (it can be even opposite) from social and economic self-determination types. The moral self-determination criteria are internal; the social and economic criteria are set by the social comparison, i.e., they are external.

3. Implementation of moral self-determination of a specific behavior is focused on other people; implementation of social and economic self-determination is focused on the subject himself.

4. The shell of the moral self-determination is less flexible than it is in context of social and economic self-determination.

5. People can control their social and economic perspectives. A change of moral self-determination is less controllable, there are no clear pictures of perspectives or coherent expectations in this case.

6. In case of moral self-determination, prolonged influence of socialization agents is more significant than it is for social and economic self-determination.

7. It is impossible to evaluate possibilities and resources for moral self-determination. Moral self-determination frequently develops spontaneously under the influence of self-determination agents and normative and non-normative life events. It is necessary to have some basic level of moral development to be able to control one's own moral features.

On the basis of analysis of conceptual research schemes, elements of moral (as an example of basic type), social and economic (as an example of private type) self-determination similarities, we suggest the following rules of studying basic and special self-determination types. They expand those given by A.L. Zhuravlev and 
A.B. Kupreichenko (2007), who suggested principles of research on personality and group self-determination.

1. During the study of the basic type of self-determination, special types can be ignored or used as an example of the basic type's manifestation (for example, moral self-determination manifests in the economic field as moral attitude toward money and labor).

2. During the study of special self-determination types, a basic type must be taken into account; spiritual self-determination or its components as well as life self-determination must be included in conceptual model.

3. The following must be considered in the structure of self-determination: basic self-determination is the de-facto core of the special type. The shell is an outward manifestation of any self-determination type; it is a specific area of application for a special type of self-determination.

4. During the study of the special type of self-determination, it is necessary to distinguish effective, procedural and formal-dynamic characteristics. While researching a basic type of self-determination, we assume less clarity and measurability of these characteristics; thus, they can be shown less in the conceptual scheme. However, this assumption requires more analysis.

5. It is necessary to take into account micro-, meso- and macro-level factors during the study of both special and basic self-determination types.

\section{Conclusions}

High topicality of self-determination research is determined by two factors: 1) the need of psychological science to move into a study of an integral phenomenon and 2) prolonged socio-economic instability in Russian society, which launches the processes of self-determination in all of the social classes.

Self-determination implies active self-development of a personality, search of one's life position, making a decision in a critical situation. The process continues throughout one's entire life.

There are many subtypes of self-determination. Not all of them are researched well enough.

The self-determination phenomenon has different interpretations in foreign and Russian psychological school of thought.

There are three groups of methods that describe self-determination structure in the Russian psychological school of thought: 1) those based on the relation concept, 2) those based on motivation and 3) structural-dynamic. The last type is the most studied.

The goal of research was attained. Based on the multi-level model of a group and personal self-determination, suggested by A.L. Zhuravlev and A.B. Kupreichenko, studies of different types of self-determination (basic and special (moral, social, economic)) have been conducted. The analysis of conceptual research schemes with respect to elements of moral and social and economic self-determination similarity has been performed. Principles of basic and private self-determination research were suggested and marked for further empirical searches for differences between elements and indexes of mentioned self-determination types. 
Application of an aforementioned model to the study of some types of selfdetermination makes it possible to research a large number of elements (values, ideals, concepts, strategies, needs, capabilities, self-concepts, etc.) that are not as isolated as they used to be studied, but the model requires complex research and building an interconnected structure. This method is difficult to carry out in an empirical study, as it requires an analysis of a large number of variables, which is labor intensive for a researcher and tiring for respondents. It is necessary to include projective methods to identify a subconscious influence of other elements of a self-determination structure on a subject's behavior. However, there are no defined guidelines for such inclusion in the self-determination rules of study.

\section{Acknowledgements}

This work was supported by the Russian Humanitarian Fund grant \# 12-3601099a1.

\section{References}

Abul'hanova-Slavskaja, K. A. (1973). O subekte psihicheskoj dejatel'nosti. [About the subject of psychic activity]. Moscow: Nauka.

Abul'hanova-Slavskaja, K. A. (1991). Strategija zhizni [Strategies of life]. Moscow: Mysl'.

Bashaeva, I.I. (2005). Psihologicheskie determinanty professionalnogo samoopredelenija studentov pedagogicheskogo kolledzha [Psychological determinants of students' professional selfdetermination in pedagogical college]. (Doctoral thesis). Russia, Habarovsk: Buryat State University.

Borisova, E. M. (1995). Professional'noe samoopredelenie: lichnostnyj aspekt. [Professional selfdetermination: personal aspect]. (Doctoral thesis). Moscow.

Bozhovich, L. I. (1968). Lichnost' i ee formirovanie v detskom vozraste [Person and his/her formation in childhood]. Moscow: Prosveshhenie.

Deci, E. L. (1980). The psychology of self-determination. Toronto: Lexington Books.

Easterbrook, J. A. (1978). The determinants of free will. NewYork: Academic Press.

Ginzburg, M. R. (1996) Psihologija lichnostnogo samoopredelenija [Psychology of personal selfdetermination]. (Doctoral thesis). Moscow: Psychological Institute Russian Academy of Education.

Guljakina, V. V. (2000). Gruppovye normy i cennosti kak faktory samoopredelenija lichnosti starsheklassnika [Group norms and values as the factors of senior pupils' personal self-determination]. (PhD thesis). Russia, Orel: Orel State Univertity.

Harre, R. (1979). Social being. Oxford: Blackwell.

Harre, R. (1983). Personal being. Oxford: Blackwell.

Klimov, E. A. (1996). Psihologija professional'nogo samoopredelenija. [Psychology of professional self-determination]. Rostov-na-Donu: Feniks.

Kuprejchenko, A. B. (2010). Nravstvenno-psihologicheskaja determinacija jekonomicheskogo samoopredelenija lichnosti i gruppy [Moral-psychological determination of person and group economic self-determination]. (Doctoral thesis). Moscow: Institute of Psychology of Russian Academy of Sciences.

Kuprejchenko, A. B., \& Vorobyeva, A. E. (2013). Nravstvennoe samoopredelenie molodezhi [Youth moral self-determination]. Moscow: RAS Psychological Institute. 
Naumova, L. A. (2005). Psihologicheskie zakonomernosti dinamiki professional'nogo samoopredelenija studentov na primere inzhenernyh special'nostej [Psychological regularities of students' professional self-determination dynamics on the example of engineering speciality]. ( $\mathrm{PhD}$ thesis). Russia, Yaroslavl: Tver Regional Institute of Teachers Training.

Padalko, O. V. (1998). Professional'noe samoopredelenie molodogo specialista s vysshim obrazovaniem $v$ sovremennom rossijskom obshhestve [Young high educated spesialist's professional self-determination in modern Russian society]. (PhD thesis). Saint-Petersburg: Saint Petersburg State University.

Rubinshtejn, S. L. (1973). Problemy obshhej psihologii [Problems of general psychology]. Moscow: Pedagogika.

Ryan, R. M., \& Deci, E. L. (2000). Self-determination theory and the facilitation of intrinsic motivation, social development and well-being. American Psychologist, 55(1), 68-78. doi: 10.1037/0003-066X.55.1.68

Rychlak, J. (1979). Discovering free will and personal responsibility. New York: Oxford University Press.

Rychlak, J. (1981). Introduction to personality and psychotherapy. Boston: Houghton Mifflin.

Rychlak, J. (1984). The nature and challenge of teleological psychological theory. In J.R. Royce \& L.P. Mos (Eds.) Annals of theoretical psychology. Vol. 2. (pp. 115-150). New York: Plenum Press. doi: 10.1007/978-1-4757-9191-4_11

Safin, V. F. (1986). Psihologija samoopredelenija lichnosti [Psychology of person self-determination]. Russia, Sverdlovsk: Sverdlovsk Pegagogical Institute.

Safin, V. F., \& Nikov, G. P. (1984). Psihologicheskij aspekt samoopredelenija lichnosti [Psychological aspect of person self-determination]. Psihologicheskij Zhurnal [Psychological Journal], 5(4), 65-73.

Smirnov, L. M. (2003). Bazovye cennosti i «anticennosti» sovremennyh rossijan [Basic values and "anti-values" of modern Russians]. In A.V. Rjabov \& E.Sh. Kurbangaleeva (Eds.) $B a-$ zovye cennosti rossijan: Social'nye ustanovki. Zhiznennye strategii. Simvoly. Mify [Basic values of the Russians: Social settings. Life strategies. Symbols. Myths]. (pp. 16-26). Moscow: Dom intellektual'noj knigi.

Tageson, W. (1982). Humanistic psychology: a synthesis. Homewood (Ill.): The Dorsey Press.

Ugarova, M. G. (2004). Problema struktury professional'nogo samoopredelenija v trudah rossijskih psihologov [Problem of professional self-determination structure in works of Russian psychologists] In V.V. Kozlov (Ed.) Socialnaja psihologija XXI stoletija [Social psychology of the XXth century]. Vol. 2. (pp. 320-324). Russia, Yaroslavl: MAPN.

Zhuravlev, A. L., \& Kuprejchenko, A. B. (2007). Jekonomicheskoe samoopredelenie. Teorija i jempiricheskie issledovanija [Economic self-determination. Theory and empirical research]. Moscow: RAS Psychological Institute.

Zhuravlev, A. L., \& Kuprejchenko, A. B. (2008). Samoopredelenie lichnosti i gruppy: osnovnye priznaki i principy organizacii issledovanija [Person and group self-determination: main attributes and principles of research]. In A.V. Kapcov (Ed.) Professional'noe i lichnostnoe samoopredelenie molodezhi v period social'no-jekonomicheskoj stabilizacii Rossii: Materialy vtoroj Vseros. nauch.-prakt. konf. Samara, 30 ijunja - 1 ijulja 2008 g. (pp. 3-10) [Professional and personal self-determination of the youth in the period of socioeconomic stabilization in Russia. Proceedings of the 2nd Russian scientific-applied conference. June, 30 - July, 1, 2008]. Russia, Samara: Samara Humanitarian Academy. 